\title{
WATER REUSE IN BRAZILIAN MANUFACTURING FIRMS
}

\author{
José Gustavo Féres \\ IPEA \\ Alban Thomas \\ INRA e Université de Toulouse 1 \\ Arnaud Reynaud \\ INRA e Université de Toulouse 1
}

\begin{abstract}
This paper examines the factors influencing manufacturing firms' water reuse decision and analyzes whether the structure of intake water demand differs between firms that adopt water reuse practices and those which do not. The first stage of the estimation model involves a Probit analysis of the water reuse decision and the second stage employs an endogenous switching regression to estimate the intake water demand equations. Results suggest that water charges may act as an effective mechanism in inducing firms to undertake water reuse investments and in reducing intake water demand. Estimates of the water demand price elasticities indicates that plants that reuse water are more sensitive to water price increases than plants without access to reuse technologies.
\end{abstract}

Keywords: Water Reuse, Industrial Water Demand.

Resumo: Este artigo examina os fatores que influenciam a decisão das firmas em adotar práticas de reúso de água e avalia se esta decisão afeta o comportamento das firmas em relação à demanda por recursos hídricos. Para isso, estima-se um modelo econométrico em dois estágios. O primeiro estágio analisa a decisão da firma de se reutilizar ou não a água através de um modelo Probit. No segundo estágio são estimadas equações de demanda de água separadamente para as firmas que reutilizam água e as demais. Os resultados sugerem que a cobrança pelo uso da água pode ser um instrumento eficaz de incentivo à adoção de práticas de reúso e também na redução da demanda de água, promovendo desta forma a conservação de recursos hídricos. A estimação das elasticidades-preço das demandas de água mostra ainda que as firmas que reutilizam água reagem de maneira mais forte a variações no preço da água que aquelas que não adotam práticas de reúso.

Palavras-chave: Reúso de água, demanda industrial de água.

Área ANPEC: 10 - Economia Agrícola e do Meio Ambiente

JEL: Q21, Q25, L5. 


\section{Introduction}

Due to the rapid demographic and industrial growth, many Brazilian urban areas have been experiencing water scarcity problems related to water quality degradation and increasing demand for competing uses. At the same time, the high cost of expanding supplies and growing environmental awareness expose the limits of a supply-side management approach in meeting this rising demand. The situation claims for an appropriate mix of demand-side and supply-side policy measures so as to reorient urban water management on to a more sustainable path. Under this backdrop of a more integrated approach, water reuse is viewed as an important component for the sustainable management of water supplies.

Water reuse is generally defined as the use of treated wastewater for beneficial purposes. One may identify several benefits associated with this practice. First, water reuse leads to reduced freshwater withdrawals and wastewater treatment volumes, with associated cost savings. In addition to that, by meeting some of the water demand through water reuse, additional infrastructure requirements for expanding water supply and the resulting financial and environmental impacts can be reduced. Finally, water reuse can free up existing water supply to be allocated to more quality-demanding uses, such as for drinking, thereby contributing to more sustainable resource utilization ${ }^{1}$.

Industrial activities present a number of opportunities for water reuse. Potential applications include cooling tower makeup water, boiler feed water, process water, floor washing and irrigation of green spaces, among others. A report published by Statistics Canada (2002) provides evidence that recycling rates within industrial activities in Canada are higher than in most other sectors, reinforcing the prominent role industrial reuse may play in water resources conservation.

Notwithstanding the wide range of potential applications and the economic and environmental benefits associated to industrial water reuse, there is a paucity of econometric studies analyzing this facet of water use. To our knowledge, Renzetti (1992) and Dupont and Renzetti (2001) are the only works that incorporated water reuse within an industrial water demand econometric model. Both studies find that water intake and recirculation are substitute inputs. This result suggests that, if intake water prices were to rise, manufacturing firms would employ more water recirculation as a means of meeting their water needs. However, several issues remain to be investigated, such as assessing the determinants of reuse technology adoption.

This paper aims at investigating which factors play a role in explaining firms' decisionmaking concerning water reuse and whether the structure of intake water demand differs between firms that adopt water reuse practices and those which do not. If economic factors are significant in explaining water reuse decisions or if the structure of water demand differs between firms with water reuse and the others, then these findings may have important implications on whether economic instruments such as water charges

\footnotetext{
${ }^{1}$ See Anderson (2003) and UNEP (2005) for more detailed discussions about the benefits of water reuse.
} 
could induce firms to adopt water reuse technologies or on the way planners forecast water demand growth.

In order to assess these issues, we use an econometric model based on a two-stage estimation procedure. First, a Probit model is estimated with the dependent variable reflecting firms' choice about water reuse. Second, an endogenous switching regression model is used to derive estimates of intake water demand. The model is estimated using a detailed cross-sectional survey of 488 industrial plants located within the Paraíba do Sul river basin, Brazil.

This paper is organized as follows. Section 2 presents the econometric model. Section 3 describes the database and defines the variables used in the empirical application. Estimation results and their policy implications are presented in Section 4. Lastly, Section 5 summarizes the main results.

\section{Econometric Model}

We assume firm's decision-making may be represented by a two stage process. First, the firm must decide whether or not to reuse water (i.e., to invest in water reuse technology). Second, the firm must choose the quantity of water intake, conditional on the previous decision concerning water reuse.

The endogenous switching regression model can properly capture the features of the firm's decision-making process and provide unbiased estimates of the water demand coefficients. The model consists of distinct water demand equations for firms that reuse water and those which do not and an equation for the water reuse decision. Define $Q_{i}$ as the annual quantity of intake water, $I^{*}$ as a latent variable that determines water reuse decision, $I$ as an indicator variable that equals 1 if firm $i$ reuses water and equals zero otherwise, $X$ as a vector of observed characteristics that affects water demand and $\mathrm{Z}$ as a vector of observed characteristics that affect reuse decision. The general form of the statistical model may be expressed by the following equations:

$Q_{i}=g\left(X_{1 i}, \alpha\right)+\mu_{1 i} \quad$ if $I_{i}=1$

$Q_{i}=h\left(X_{2 i}, \beta\right)+\mu_{2 i} \quad$ if $I_{i}=0$

$I^{*}=\gamma Z_{i}+\varepsilon_{i}$

$I=1$ if and only if $I^{*}>0$

$=0$ if and only if $I^{*} \leq 0$

where $\mathrm{g}($.$) and \mathrm{h}($.$) are the intake water demand equations for the firms that reuse water$ and those which do not, respectively, $\alpha, \beta$ and $\gamma$ are the parameters to be estimated and $\mu_{1 i}, \mu_{2 i}$ and $\varepsilon_{i}$ are error terms. The error terms are assumed to have a trivariate normal distribution, with mean vector zero and covariance matrix 


$$
\operatorname{Cov}\left(\mu_{1}, \mu_{2}, \varepsilon\right)=\left(\begin{array}{ccc}
\sigma_{11}^{2} & \sigma_{12} & \sigma_{1 \varepsilon} \\
\sigma_{12} & \sigma_{22}^{2} & \sigma_{2 \varepsilon} \\
\sigma_{1 \varepsilon} & \sigma_{2 \varepsilon} & 1
\end{array}\right)
$$

An important implication of the assumed error structure is that if there are unobserved variables affecting both water demand and the reuse decision, $\mu_{1 i}$ and $\mu_{2 i}$ will be correlated with $\varepsilon_{i}$. In this case, the error terms in equations (1) and (2), conditional on the sample selection criterion (i.e., the reuse decision), have a nonzero expected value, what implies that OLS estimates of the coefficients in the water demand equations will be biased. In order to remove the bias associated with nonrandom sample selection, equations (1) and (2) are augmented in the following fashion:

$$
\begin{array}{ll}
Q_{i}=g\left(X_{1 i}, \alpha\right)+\sigma_{1 \varepsilon} \frac{\phi\left(\gamma^{\prime} Z\right)}{\Phi\left(\gamma^{\prime} Z\right)}+\zeta_{1 i} & \text { if } I_{i}=1 \\
Q_{i}=h\left(X_{2 i}, \alpha\right)+\sigma_{2 \varepsilon} \frac{-\phi\left(\gamma^{\prime} Z\right)}{\left(1-\Phi\left(\gamma^{\prime} Z\right)\right)}+\zeta_{2 i} & \text { if } I_{i}=0
\end{array}
$$

where $\phi($.$) and \Phi($.$) are the normal probability and cumulative density functions,$ respectively, and the new errors $\zeta_{1}=\mu_{1}+\sigma_{1 \varepsilon}$ and $\zeta_{2}=\mu_{2}+\sigma_{2 \varepsilon}$ are uncorrelated. The additional variables given by the expressions $\frac{\phi\left(\gamma^{\prime} Z\right)}{\Phi\left(\gamma^{\prime} Z\right)}$ and $\frac{-\phi\left(\gamma^{\prime} Z\right)}{\left(1-\Phi\left(\gamma^{\prime} Z\right)\right)}$ are the inverse Mill's ratios, and they can be computed using the parameter estimates of the reuse decision equation (3). The associated coefficients to the inverse Mill's ratios, $\sigma_{1 \varepsilon}$ and $\sigma_{2 \varepsilon}$, give the correlation between the water demand and the reuse decision errors. Thus, if the estimates of these coefficients are found to be statistically different from zero, the hypothesis of the absence of sample selectivity bias can be rejected.

In order to estimate the econometric model, we need to specify the explanatory variables to be included in $Z, X_{1}$ and $X_{2}$. We consider that firms' decision to reuse water will depend on input prices, firm's characteristics (production level, activity sector, etc.) and technical and regulatory characteristics (water supply source, basic water use to which water is put, etc.). So, we adopt the following specification for the reuse equation

$I=\gamma_{0}+\gamma_{Y} Y+\sum_{j=1}^{J} \gamma_{j} P_{j}+\sum_{l=1}^{L} \gamma_{l} Z_{l}+\varepsilon$

where $Y$ is the production level, $P_{j}$ is the price of input $j(j=1, \ldots, J)$ and $Z$ is a vector of water-related, technical and institutional characteristics that may affect reuse decisions.

Regarding the water intake demand equations, we assume that the only difference in the vector of explanatory variables $X_{1}$ and $X_{2}$ is that the former includes the water reuse price. This feature accounts for the fact that recycled water may be a substitute good for water withdrawals, and so plants that reuse water will take into consideration the reuse cost in their intake demand decisions. The remaining components for $X_{1}$ and $X_{2}$ are the same, with both including the freshwater price, the production level and the basic end use to 
which water is put. We assume that the intake demand equations have a log-log functional form:

$$
\begin{aligned}
& \ln Q_{i}=\alpha_{0}+\alpha_{Y} \ln Y+\alpha_{F W A T} \ln P_{F W A T}+\alpha_{R W A T} \ln P_{R W A T}+\sum_{l=1}^{L} \alpha_{l} Z_{l}+\sigma_{1 \varepsilon} \frac{\phi\left(\gamma^{\prime} Z\right)}{\Phi\left(\gamma^{\prime} Z\right)}+\zeta_{l i} \text { if } I=1 \\
& \ln Q_{i}=\beta_{0}+\beta_{Y} \ln Y+\beta_{F W A T} \ln P_{F W A T}+\sum_{l=1}^{L} \beta_{l} Z_{l}+\sigma_{2 \varepsilon} \frac{-\phi\left(\gamma^{\prime} Z\right)}{\left(1-\Phi\left(\gamma^{\prime} Z\right)\right)}+\zeta_{2 i} \text { if } I=0
\end{aligned}
$$

where $P_{F W A T}$ is the freshwater use price and $P_{R W A T}$ is the water reuse price.

The estimation procedure is the following. First, the reuse decision equation (6) is estimated using a Probit model. The parameters $\gamma$ are then used to compute the inverse Mill's ratios. Second, the switching regression model is applied to the intake water demand equations (7) and (8) to derive estimates of the coefficients $\alpha, \beta$ and $\sigma$.

\section{Data description}

The data used for estimating the model come from the industrial water use survey conducted by the Institute for Applied Economic Research (IPEA) at the Paraíba do Sul river basin. The Paraíba do Sul river basin is one of the most industrialized regions in Brazil, accounting for about 10 per cent of the country's GDP. The survey collected comprehensive water-related information on 488 industrial plants located within the basin area for the year 2002. The questionnaire covered several dimensions of industrial water use, including water intake, pre-treatment, recirculation, plus wastewater treatment and discharge. Total quantity and cost were reported for each of these water use components. The survey also collected economic data on firms' output and production factors in order to relate water use with the production process. Due to missing data required to construct our econometric model, our sample consists of 447 observations.

The survey information is used to construct the variables necessary to estimate the coefficients of equations (6), (7) and (8). Regarding the input prices, the price of capital $\left(P_{K}\right)$ corresponds to the sum of the real interest rate and the depreciation rate. The electricity price $\left(P_{E}\right)$ is computed as the value of the electricity bill divided by the quantity of Kwh consumed. The freshwater price $\left(P_{F W A T}\right)$ is given by the average freshwater use cost, which is computed differently depending on the water supply source. For the self-supplied plants, $P_{F W A T}$ is computed as the sum of expenditures on water withdrawal, water treatment prior to use and wastewater treatment/discharge divided by the total water quantity involved in these processes. For the plants connected to a public water supply network, it is calculated as the value of the water bill divided by the total water quantity. The reuse price $\left(P_{R W A T}\right)$ is given by the average cost of water recycling reported by the plants. We have also computed the water cost share for each industrial facility (WSHARE), which corresponds to the sum of water-related expenditures divided by the plant's production costs. Finally, the level of output $(Y)$ is measured by the production value. 
Several dummy variables representing plant's water- and environmental-related characteristics were also constructed from the questionnaire answers. Variable SSUPPLY refers to the type of water supply source, taking the value of 1 if the plant is self-supplied and 0 if the plant is connected to the public water network. ISO14000 is a dummy equal to 1 if the firm has an ISO 14000 accreditation and 0 otherwise. Dichotomous variables were also created to represent three main basic end use to which water is put: cooling/condensing/steam generation purposes (COOL_STEAM), processing (PROCESS) and sanitary or miscellaneous purposes (SANIT). Variable D_INTER refers to the firms' ownership, taking the value of 1 if the firm is foreign-owned and 0 otherwise ${ }^{2}$. Lastly, variable WCHARGE_ACCEPT represents firm's receptiveness regarding water charge, being equal to 1 if the firm approves the water charge implementation and 0 if the firm is opposed to this policy instrument ${ }^{3}$.

A preliminary analysis of the data allows us to identify some patterns regarding industrial water reuse. Taken as a whole, the number of plants that reuse water is relatively small: out of the 447 facilities, only 63 (14\%) stated to adopt reuse practices. However, a closer analysis of the question suggests that firms' behavior vary significantly according to some economic, water-related and environmental-related characteristics.

Table 1 presents descriptive statistics of some economic and water-related variables conditional on plants' decisions regarding water reuse. The average water intake for the subgroup of plants that reuse water corresponds to more than four times the average for the plants that do not undertake reuse activities. It can also be observed that the average freshwater use price is slightly higher for the subgroup of plants that do not reuse water. This can be explained by the fact that a large proportion of plants that do not undertake reuse practices rely on the public water supply system, whose average tariffs are usually higher than the unit water cost faced by self-supplied firms. More interestingly, for the plants that adopt water reuse practices, the reuse price $P_{R W A T}$ is approximately one third of the freshwater use price. The significant cost difference may provide plants with incentives for substituting freshwater intake by wastewater reuse. Water-related expenditures seems to be more significant for the plants that reuse water: while the average water cost share corresponds to $1.4 \%$ of production costs for this subgroup, this share represents only $0.7 \%$ of production costs for plants without access to water reuse technologies. It should also be noted that the average output value of the plants that undertake reuse practices is far above the average value produced by the plants that do not adopt such practices.

\footnotetext{
${ }^{2}$ We classify a firm as "foreign-owned" if foreign capital represents more than $50 \%$ of the firm's capital structure.

${ }^{3}$ Water charges were implemented in the Paraíba do Sul river basin in March 2003 and they have faced some resistance among industrial water users in this early implementation stage. For an analysis of industrial receptiveness to water charges, see Féres et al. (2005).
} 
Table 1: Descritptive statistics for economic and water-related variables

\begin{tabular}{|c|c|c|c|c|c|}
\hline \multirow{2}{*}{ Variable } & \multirow{2}{*}{ Unit } & \multicolumn{2}{|c|}{$\begin{array}{c}\text { Plants without water reuse } \\
(384 \text { observations })\end{array}$} & \multicolumn{2}{c|}{$\begin{array}{c}\text { Firms with water reuse } \\
\text { (63 observations) }\end{array}$} \\
\cline { 3 - 6 } & & Mean & Std. Dev. & Mean & Std.Dev. \\
\hline$Y$ & $\mathrm{R} \$$ & 3.60 e+07 & $4.06 e+08$ & $9.27 e+07$ & $2.56 e+08$ \\
\hline$P_{F W A T}$ & $\mathrm{R} \$ \mathrm{~m}^{3}$ & 2.74 & 2.21 & 2.46 & 2.25 \\
\hline$P_{R W A T}$ & $\mathrm{R} \$ / \mathrm{m}^{3}$ & - & - & 0.88 & 0.89 \\
\hline$Q$ & $\mathrm{~m}^{3} /$ year & 210,984 & 665,487 & 46,051 & 290,988 \\
\hline WATSHARE & & 0.0077 & 0.0140 & 0.0144 & 0.0302 \\
\hline WATPRDVTY & $\mathrm{R} \$ / \mathrm{m}^{3}$ & 4,103 & 9,567 & 6,657 & 24,549 \\
\hline$P_{K}$ & & .12 & .0307 & .12 & .0332 \\
\hline$P_{E}$ & $\mathrm{R} \$ / \mathrm{Kwh}$ & .33 & .260818 & .34 & .4755492 \\
\hline
\end{tabular}

Note: Y - Firm's output value; $\mathrm{P}_{\mathrm{FWAT}}$-freshwater use price; $\mathrm{P}_{\mathrm{RW}}$ - water reuse price; $\mathrm{Q}$ - annual intake water demand; WATSHARE - water cost share; WATPRDVTY - water productivity; $\mathrm{P}_{\mathrm{K}}$ - capital price; $\mathrm{P}_{\mathrm{E}}-$ electricity price.

Table 2 presents some descriptive statistics regarding the qualitative variables. It can be seen that the proportion of self-supplied plants that reuse water is considerably larger than among those connected to public supply networks. This feature may be related to the fact that self-supplied plants are usually large water users, for which water reuse investments may imply in significant cost savings. Water reuse is also more observed among plants with ISO14000 accreditation and foreign-owned plants. These figures raise two questions: whether foreign-owned firms have a different water-related behavior than their domestic counterparts and whether environmental certification leads to improved water management practices. The percentage of plants that reuse water is higher among those facilities whose managers declared to approve the water charge implementation in the river basin. Finally, water reuse practices tend to be more common in plants that use water mainly for cooling, condensing and steam generation purposes. In fact, cooling systems are characterized by high water demands and low water quality requirements, what makes this application an ideal candidate for reusing industrial waste streams. On the other hand, a low percentage of firms which use water for sanitary applications invest in reuse. 
Table 2: Descriptive statistics for dichotomous variables

\begin{tabular}{|c|c|c|c|}
\hline Variable & & Number of plants & $\begin{array}{l}\text { Percentage of plants adopting } \\
\text { reuse practices }\end{array}$ \\
\hline \multirow[t]{2}{*}{ SSUPPLY } & Yes & 177 & $24.9 \%$ \\
\hline & No & 273 & $7.0 \%$ \\
\hline \multirow[t]{2}{*}{ ISO14000 } & Yes & 23 & $30.4 \%$ \\
\hline & No & 424 & $13.2 \%$ \\
\hline \multirow[t]{2}{*}{ D_INTER } & Yes & 37 & $29.7 \%$ \\
\hline & No & 410 & $12.7 \%$ \\
\hline \multirow[t]{2}{*}{ WCHARGE_ACCEPT } & Yes & 221 & $16.7 \%$ \\
\hline & No & 226 & $11.5 \%$ \\
\hline COOL_STEAM & & 29 & $44.8 \%$ \\
\hline PROCESS & & 139 & $21.6 \%$ \\
\hline SANIT & & 279 & $7.2 \%$ \\
\hline
\end{tabular}

Note: SSUPPLY - dummy variable for self-supplied plants; ISO14000 - dummy variable for firms with ISO 14000 accreditation; D_INTER - dummy variable for foreign-owned firms; WCHARGE_ACCEPT dummy variable for plants receptive to water charge implementation; COOL_STEAM, PROCESS, SANIT - dummy variables for basic water end use purpose.

\section{Estimation Results}

The results of the Probit analysis of the factors affecting the water reuse decision are presented in Table 3. Recall that the dependent variable $I$ is defined as an indicator that equals 1 if the plant reuses water and equals zero otherwise. Thus, a positive coefficient indicates that the variable increases the likelihood of water reuse.

We consider two specifications of the reuse decision equation in Table 3. The specification in column (1) does not control for sector fixed effects. The specification in column (2) includes a set of dummy variables representing seven industrial activity sectors: food and beverages, rubber and plastic products, pulp and paper, chemicals, nonmetallic products, iron and steel products and others. The sector dummy variables in column (2) intend to account for sector-specific features that may influence the water reuse decision and are not addressed by the other independent variables. The comparison between the two specifications shows that failing to account for sector fixed effects may have some important implications in terms of the statistical significance of the coefficient estimates, as illustrated by the water price and output variables ( $P_{W}$ and $Y$, respectively). So, we focus our analysis of the water reuse decision equation on the coefficient estimates of the model specified in column $(2)^{4}$.

\footnotetext{
${ }^{4}$ Moreover, the likelihood ratio test regarding the sector dummies also provides some evidence that one should take into account the sector fixed effects. In fact, since the model in column (1) can be considered a restricted version of the one specified in column (2), we can apply a likelihood ratio test to choose between the two specifications. The computed likelihood ratio statistic is LR $=-2((-148.95503)-(-142.34224))=$ 13.23 , which is above the $95 \%$ critical value from the chi-squared distribution with 6 degrees of freedom $\chi^{2}(6)=12.59$. So, at the 5\% significance level, we reject the hypothesis that the sector dummies are equal to zero. This result provides evidence that one should choose the water reuse equation specified in column (2).
} 
Table 3: Probit results of water reuse decision equation

\begin{tabular}{|c|c|c|c|c|}
\hline \multirow[b]{3}{*}{ Independent Variable } & \multirow{2}{*}{\multicolumn{2}{|c|}{$(1)$}} & \multirow{2}{*}{\multicolumn{2}{|c|}{ (2) }} \\
\hline & & & & \\
\hline & Coefficients & Marginal effects & Coefficients & Marginal effects \\
\hline$\overline{\ln Y}$ & $\begin{array}{c}0.105 \\
(0.055)\end{array}$ & 0,019 & $\begin{array}{l}0.119^{*} \\
(0.057)\end{array}$ & 0,020 \\
\hline \multirow[t]{2}{*}{$P_{k}$} & $-5.558^{*}$ & -0.988 & $-4.696^{*}$ & -0.774 \\
\hline & $(2.272)$ & & $(2.396)$ & \\
\hline \multirow[t]{2}{*}{$\ln \mathrm{P}_{\mathrm{w}}$} & 0.115 & 0,020 & $0.135^{*}$ & 0,022 \\
\hline & $(0.063)$ & & $(0.068)$ & \\
\hline \multirow[t]{2}{*}{$\ln P_{E}$} & 0,150 & 0,027 & 0,129 & 0,021 \\
\hline & $(0.140)$ & & $(0.140)$ & \\
\hline ISO14000 & $\begin{array}{c}0,054 \\
(0.389)\end{array}$ & 0,010 & $\begin{array}{c}0,048 \\
(0.412)\end{array}$ & 0,008 \\
\hline D_INTER & $\begin{array}{c}0,112 \\
(0.306)\end{array}$ & 0,021 & $\begin{array}{c}0,042 \\
(0.313)\end{array}$ & 0,007 \\
\hline SSUPPLY & $\begin{array}{l}0.642^{* *} \\
(0.189)\end{array}$ & 0,126 & $\begin{array}{l}0.675^{* *} \\
(0.197)\end{array}$ & 0,124 \\
\hline PROCESS & $\begin{array}{l}0.440^{*} \\
(0.190)\end{array}$ & 0,087 & $\begin{array}{l}0.495^{\star} \\
(0.211)\end{array}$ & 0,092 \\
\hline COOLING/STEAM & $\begin{array}{l}0.985^{\star *} \\
(0.306)\end{array}$ & 0,272 & $\begin{array}{l}0.839^{*} \\
(0.330)\end{array}$ & 0,210 \\
\hline CHARGE_ACCEPT & $\begin{array}{c}0,250 \\
(0.168)\end{array}$ & 0,045 & $\begin{array}{c}0.306 \\
(0.171)\end{array}$ & 0,051 \\
\hline RUBBER/PLASTICS & & & $\begin{array}{l}1.108^{\star *} \\
(0.379)\end{array}$ & 0,301 \\
\hline PULP\&PAPER & & & $\begin{array}{c}1,018 \\
(0.650)\end{array}$ & 0,282 \\
\hline CHEMICAL & & & $\begin{array}{c}0,398 \\
(0.379)\end{array}$ & 0,081 \\
\hline NONMET & & & $\begin{array}{c}0.828^{*} \\
(0.411)\end{array}$ & 0,207 \\
\hline IRON\&STEEL & & & $\begin{array}{l}0.655^{*} \\
(0.331)\end{array}$ & 0,142 \\
\hline OTHER & & & $\begin{array}{c}0,388 \\
(0.288)\end{array}$ & 0,065 \\
\hline \multirow[t]{2}{*}{ Constant } & $\begin{array}{c}-2.480^{* *} \\
(0.767) \\
\end{array}$ & & $\begin{array}{c}-3.416^{* *} \\
(0.839) \\
\end{array}$ & \\
\hline & $\begin{array}{l}\text { Number of obse } \\
\text { Log likelihood: } \\
\text { Chi-squared(10) } \\
\text { Percent correctly } \\
\text { reuse: } 21 \% \\
\text { no reuse:99\% }\end{array}$ & $\begin{array}{l}\text { ations: } 447 \\
8.95503 \\
61.30 \\
\text { redicted }\end{array}$ & $\begin{array}{l}\text { Number of obse } \\
\text { Log likelihood: } \\
\text { Chi-squared(16) } \\
\text { Percent correctly } \\
\text { reuse: } 14 \% \\
\text { no reuse: } 98 \%\end{array}$ & $\begin{array}{l}\text { ations: } 447 \\
2.34224 \\
77.71 \\
\text { redicted }\end{array}$ \\
\hline
\end{tabular}

Note: Dependent varible is defined as $I=1$ if the plant reuses water and $I=0$ otherwise. Robust standard errors in parentheses. One asterisk $\left({ }^{*}\right)$ indicates significance at a $5 \%$ level. Two asterisks $\left({ }^{* *}\right)$ indicates significance at a $1 \%$ level. 
The estimated coefficients provide several insights into the water reuse decision-making process. First, the positive and significant coefficient of the output variable $Y$ indicates that large plants are more likely to reuse water, while the coefficient of the dummy variable SSUPPLY suggests that self-supplied plants also have a higher probability of adopting water reuse practices. Since large plants and self-supplied facilities can in general be characterized as large water users, these findings suggest that the amount of water needs will be an important determinant to the water reuse decision. In fact, for large water users, investing in water reuse technologies may imply in significant cost savings.

Considering the input price variables, the estimated negative coefficient for $P_{K}$ indicates that increases in the capital price are likely to reduce the probability of plants to adopt water reuse practices. This feature suggests that water reuse technologies are capital intensive. Reuse decisions also seem to be affected by the water price: the positive coefficient of $P_{W}$ suggests that plants facing higher water prices are more likely to reuse water ${ }^{5}$. On the other hand, the lack of statistical significance for $P_{E}$ suggests that electricity prices do not seem to play a role on water reuse decisions.

These findings provide some evidence that the water charge mechanism implemented in the Paraíba do Sul river basin may act as an effective instrument for inducing firms to undertake water reuse investments. Since plants are more likely to reuse water the higher the water price, policymakers could increase the value of water charges so as to provide firms with incentives to implement water reuse practices. Alternatively, as reuse decisions seem also to be influenced by the capital price, part of the water charge revenues collected within the Paraíba do Sul river basin could be used to provide subsidized credits to firms intending to adopt water reuse practices.

Regarding the basic water end use, the positive and significant coefficients of the variables PROCESS and COOL_STEAM indicate that, when compared with plants whose basic water end use consists of sanitary applications, plants that use water mainly for processing and cooling or steam generation purposes have a higher probability of adopting water reuse practices. In particular, it can be observed that plants that use water mainly for cooling/steam generation have a probability of adopting water reuse practices $21 \%$ higher than plants that uses water for sanitary purposes. This result is in line with Scharf et al. (2002) that verified that recycling technologies in the Canadian industrial sector are in general used for process water and cooling, condensing and steam generation.

Concerning the environmental-related variables, it should be noted that the coefficients associated to the dummy variables ISOI4000 and CHARGE_ACCEPT are not statistically significant. This means that neither the ISO14000 accreditation nor firms' receptiveness

\footnotetext{
${ }^{5}$ We have also estimated the reuse decision equation using the variable WATSHARE instead of $P_{W}$. Estimated coefficients were quite similar to the ones found in column (2) at Table 3. As expected, we found that higher water cost shares increase the likelihood of water reuse. On the other hand, when we include both variables in the equation, they are not statistically significant. This may be attributed to the colinearity between WATSHARE and $P_{W}$.
} 
regarding water charges seem to play a role on firms' decisions regarding water reuse. Similarly, the lack of statistical significance of $D \_I N T E R$ indicates that foreign-owned firms' behavior regarding water reuse is not different from their domestic counterparts.

The sector dummies show that plants belonging to the rubber and plastic products (RUBBER/PLASTIC), nonmetallic products (NONMET) and iron and steel (IRON\&STEEL) sectors are more likely to adopt water reuse practices. Once again, this feature is in line with the evidence provided by Tate and Scharf (1996) and Scharf et al. (2002), who have found that recirculation indexes for these sectors are above the average for the Canadian industry as a whole.

Finally, before moving to the analysis of the water demand equations, we comment on the predictive ability of our water reuse decision model. The model predicts 385 of 447 (or $85.9 \%$ ) of the observations correctly. Notwithstanding this relatively high correctly predicted rate, it is noteworthy that nearly all correct predictions concern the "no water reuse" subgroup (98\% of correct predictions), while the percentage of correct classifications for the plants with water reuse is quite low (14\%). Nevertheless, this low percentage regarding the water reuse subgroup should not be attributed to a flaw in our Probit model, but a consequence of the unbalanced feature of the database and the threshold value chosen for the prediction rule.

In fact, we adopt the usual prediction rule: plant $i$ is predicted to adopt water reuse practices whenever the predicted probability of water reuse (denoted by $P_{i}$ ) is higher than the threshold value 0.5 . That is to say, $I_{i}=1$ if $P_{i}>0.5$ and $I_{i}=0$ otherwise. However, using 0.5 as the threshold value is not always appropriate. An important and often overlooked result in the estimation of models with dichotomous dependent variables is that the average predicted probability generated by most estimation methods is exactly equal to the proportion of ones in the sample ${ }^{6}$. Thus, if the sample is unbalanced towards one possible outcome, the average predicted probability will be very different from 0.5 . This is the case of our sample, where only $14 \%$ of the plants reuse water. Under such circumstances, only extreme combinations of the independent variables would generate a predicted probability above 0.5 , and the prediction rule is failing to predict $I=1$ for the vast majority of the cases. One could adjust the prediction rule so as to enhance the prediction performance of the model ${ }^{7}$. However, it is important to remark that, as the

\footnotetext{
${ }^{6}$ See Greene (1996) and Esquivel and Larraín (1998) for a discussion of this result. Maddala (1983) provides a proof of this result for various estimation methods.

The obvious adjustment is to reduce the threshold value so as to predict $I=1$ more often. This will increase the number of correct classifications that do have $I=1$, at the expense of increasing the number of misclassifications of plants that do not reuse water. For example, if we use as the threshold value for our

prediction rule the in-sample proportion of plants that reuse water $(14 \%)$, such that $I_{i}=1$ if $\hat{P}_{i}>0.14$ and $I_{i}=0$ otherwise, the percentage of correctly classified plants for water reuse raises from $14 \%$ to $92 \%$. On the other hand, the percentage of plants without water reuse correctly classified drops from $97 \%$ to $73 \%$. There is no correct answer as to the most adequate threshold value to choose. Sometimes, the technique of discriminant analysis is used to build a procedure to choose a threshold value. In this setting, one considers not only the number of correct and incorrect classifications, but the cost of each type of misclassification. For a description of this method, see Amemyia (1981).
} 
coefficients of the Probit regression are not chosen so as to maximize the predictive ability of the model, one should not place too much emphasis on this measure of goodness of fit. One should mainly focus on the coefficient estimates and their impact on the probability of water reuse.

Table 4 reports the coefficient estimates of the water demand equations conditional on the water reuse decision. Since the equations are estimated in double log form, the estimated coefficients of the continuous variables may be interpreted as elasticity values. Columns (1) and (3) present the results of the regressions for the plants which adopt water reuse and those which do not, respectively, where the inclusion of the inverse Mill's ratio (INVMILLS) controls for the selection bias. 


\section{Table 4: Estimated water demand coefficients}

\begin{tabular}{|c|c|c|c|c|c|}
\hline \multirow[t]{2}{*}{ Independent variables } & \multicolumn{2}{|c|}{ Plants with water reuse } & \multicolumn{2}{|c|}{ Plants without water reuse } & \multirow{2}{*}{$\begin{array}{l}\text { Pooled sample } \\
\text { (5) }\end{array}$} \\
\hline & (1) & $(2)$ & (3) & (4) & \\
\hline \multirow[t]{2}{*}{$\ln Y$} & $0.660^{* *}$ & $0.918^{\star *}$ & $0.529^{* *}$ & $0.629^{* *}$ & $0.676^{* *}$ \\
\hline & $(0.173)$ & $(0.135)$ & $(0.052)$ & $(0.044)$ & $(0.042)$ \\
\hline \multirow[t]{2}{*}{ InP $P_{\text {FWATER }}$} & $-0.528^{*}$ & -0.434 & $-0.229^{* *}$ & $-0.193^{* *}$ & $-0.175^{\star *}$ \\
\hline & $(0.226)$ & $(0.231)$ & $(0.061)$ & $(0.061)$ & $(0.060)$ \\
\hline \multirow[t]{2}{*}{ In $P_{\text {RWATER }}$} & $0.360^{*}$ & $0.373^{*}$ & & & \\
\hline & $(0.160)$ & $(0.167)$ & & & \\
\hline \multirow[t]{2}{*}{$\ln P_{E}$} & $-0.949^{*}$ & $-0.775^{*}$ & -0.189 & -0.146 & $-0.235^{\star}$ \\
\hline & $(0.371)$ & $(0.378)$ & $(0.106)$ & $(0.107)$ & $(0.106)$ \\
\hline \multirow[t]{2}{*}{ PROCESS } & 0,171 & $1.165^{*}$ & $1.034^{\star *}$ & $1.395^{\star *}$ & $1.262^{* *}$ \\
\hline & $(0.685)$ & $(0.548)$ & $(0.200)$ & $(0.174)$ & $(0.166)$ \\
\hline \multirow[t]{2}{*}{ COOLING/STEAM } & -1.737 & -0.271 & 0,454 & $1.271^{* *}$ & $0.798^{*}$ \\
\hline & $(0.937)$ & $(0.705)$ & $(0.438)$ & $(0.375)$ & $(0.311)$ \\
\hline \multirow[t]{2}{*}{ INVMILLS } & $-8.860^{*}$ & & $-4.780^{* *}$ & & \\
\hline & $(3.906)$ & & $(1.371)$ & & \\
\hline \multirow[t]{2}{*}{ RUBBER/PLASTICS } & $-4.340^{* *}$ & $-2.903^{* *}$ & $-1.817^{* *}$ & $-1.147^{* *}$ & $-1.278^{* *}$ \\
\hline & $(1.210)$ & $(1.072)$ & $(0.391)$ & $(0.346)$ & $(0.317)$ \\
\hline \multirow[t]{2}{*}{ PULP\&PAPER } & $-4.816^{* *}$ & $-4.407^{* *}$ & -0.494 & 0,286 & -0.391 \\
\hline & $(1.434)$ & $(1.481)$ & $(0.659)$ & $(0.629)$ & $(0.571)$ \\
\hline \multirow[t]{2}{*}{ CHEMICAL } & $-4.317^{* *}$ & $-3.906^{* *}$ & $-0.711^{*}$ & -0.456 & $-0.786^{*}$ \\
\hline & $(1.208)$ & $(1.242)$ & $(0.328)$ & $(0.324)$ & $(0.315)$ \\
\hline \multirow[t]{2}{*}{ NONMET } & $-2.821^{*}$ & -1.961 & $-1.560^{* *}$ & $-1.108^{* *}$ & $-1.025^{\star *}$ \\
\hline & $(1.255)$ & $(1.245)$ & $(0.367)$ & $(0.348)$ & $(0.340)$ \\
\hline \multirow[t]{2}{*}{ IRON\&STEEL } & $-3.989^{* *}$ & $-3.319^{* *}$ & $-1.211^{* *}$ & $-0.850^{* *}$ & $-1.026^{* *}$ \\
\hline & $(0.990)$ & $(0.984)$ & $(0.277)$ & $(0.261)$ & $(0.255)$ \\
\hline \multirow[t]{2}{*}{ OTHER } & $-2.688^{* *}$ & $-2.671^{*}$ & $-1.055^{* *}$ & $-0.853^{* *}$ & $-0.996^{* *}$ \\
\hline & $(0.930)$ & $(0.968)$ & $(0.217)$ & $(0.212)$ & $(0.211)$ \\
\hline \multirow[t]{2}{*}{ D_REUSE } & & & & & 0,219 \\
\hline & & & & & $(0.208)$ \\
\hline \multirow[t]{2}{*}{ Constant } & 6,511 & -4.162 & $-4.035^{\star *}$ & $-1.675^{\star *}$ & $-2.295^{\star *}$ \\
\hline & $(5.192)$ & $(2.281)$ & $(0.915)$ & $(0.624)$ & $(0.604)$ \\
\hline Observations & 63 & 63 & 384 & 384 & 447 \\
\hline R-squared & 0,72 & 0,70 & 0,62 & 0,61 & 0,62 \\
\hline
\end{tabular}

Note: Standard errors in parentheses. One asterisk $\left(^{*}\right)$ indicates significance at a $5 \%$ level. Two asterisks $(* *)$ indicates significance at a $1 \%$ level.

The water demand of both groups demonstrates the expected negative elasticity with respect to the freshwater price $\left(P_{W F R E S H}\right)$, meaning that an increase in the freshwater price results in a decrease of the water demand. The computed water price elasticity values are in line with other results found in the literature ${ }^{8}$. The finding that industrial water demand is responsive to water prices provides some evidence that water charges within the Paraíba do Sul river basin, whose implementation started in 2003, may act as an effective

\footnotetext{
${ }^{8}$ For example, Grebenstein and Field (1979) estimated elasticity values ranging from -0.33 to -0.80 for US industries. Reynaud (2002), analyzing several French industrial sectors, found demand elasticities varying between -0.10 and -0.79 . Dupont and Renzetti (2001) found similar results for Canadian firms.
} 
mechanism for water conservation. Similar results have been found by Féres and Reynaud (2004).

It is worth noting that the estimated water price elasticity is larger for the plants that reuse water $(-0.53)$ than for those which do not $(-0.23)$. There are two possible explanations for this finding. First, as already mentioned, plants that reuse water usually have larger water cost shares than plants that do not. As a result, the former can be expected to be more sensitive to changes in water prices. Second, the difference in price elasticities could be explained by the substitution possibilities between water reuse and freshwater withdrawals. When facing water price increases, plants with water reuse technologies could reduce water withdrawals by increasing water recycling volumes. Such substitution possibility would not be available to plants without reuse technologies.

In effect, the positive coefficient for the water reuse price $\left(P_{R W A T E R}\right)$ indicates that water reuse and freshwater intake are substitute factors. This feature suggests that firms with access to water reuse technologies are more flexible to adjust to freshwater price increases, providing some empirical support to the argument that substitution patterns may explain the differences in the price elasticities, as discussed above.

The elasticity with respect to the plant's level of output $Y$ is positive for both groups, as would be expected, indicating that industrial output growth will imply in higher water demand. The estimated elasticity is slightly higher for plants with water reuse, but the small difference of the computed values suggests that the intake water demand seems to respond to output growth in a quite similar way for both groups. On the other hand, the elasticities with respect to the electricity prices are quite distinct: while the estimated value was -0.95 for plants that reuse water, suggesting the electricity and intake water are complementary factors, the intake water demand of the plants that do not reuse water seems not to be responsive to the electricity price. One possible explanation for this result is that water reuse is less energy-intensive than activities related to freshwater use (intake water pumping costs, wastewater treatment and disposal, etc.), so that plants with access to reuse technologies will substitute freshwater for recycled water when faced with electricity price increases.

It should also be remarked that the estimates of the inverse Mill's ratios (INVMILLS) are significant for both subgroups. Thus, the hypothesis of absence of sample selectivity bias can be rejected. This means that if the water demand equations were estimated separately with no correction for sample selection, the coefficient estimates would like to be biased. In order to assess the effects of not taking into account the nonrandom sampling problem, we have estimated the water demand for both groups excluding the inverse Mill's ratio. The results are showed in columns (2) and (4) of Table 4. As can be seen, failing to account for sample selectivity results in the overestimation of the output elasticity, especially in the case of plants that reuse water. On the other hand, water price elasticities are underestimated. These findings suggest that ignoring sample selectivity may be a problematic issue when characterizing water demands conditioned on the water reuse decision. 
Finally, we have estimated a single water demand equation for the pooled sample, including a dummy variable for water reuse $\left(D_{-} R E\right)$. In this case, the water reuse decision is treated as exogeneous. As can be seen in column (5) of Table 4, neglecting the possibility that firms are able to choose to reuse or not water will result in biased estimates due to endogeneity problems. In particular, we can see that the water price elasticity will be underestimated.

\section{Conclusion}

Industrial activities present a number of opportunities for water reuse applications. However, notwithstanding the wide range of potential applications and the economic and environmental benefits associated to industrial water reuse, there is a paucity of econometric studies analyzing this facet of water use. This paper aimed at shedding some light on some unanswered questions regarding water reuse. In particular, the paper investigated which factors play a role in explaining firms' decision-making concerning water reuse and whether the structure of intake water demand differs between firms that adopt water reuse practices and those which do not.

In order to assess these issues, we used an econometric model based on a two-stage estimation procedure. First, a Probit model was estimated with the dependent variable reflecting plants' choice about water reuse. Second, an endogenous switching regression model was used to derive estimates of intake water demand. The model was estimated using a sample of 447 industrial plants located within the Paraíba do Sul river basin, Brazil.

The results of the Probit analysis show that the amount of water needs will be an important determinant to the water reuse decision. In fact, for large water users, investing in water reuse technologies may imply in significant cost savings associated to reduced freshwater withdrawals and wastewater treatment volumes. Input prices also seems to be relevant to the plant's choice regarding water reuse. Specifically, reuse decisions seems to be affected by water and capital prices. These findings provide some evidence that the water charge mechanism implemented in the Paraíba do Sul river basin may act as an effective instrument for inducing firms to undertake water reuse investments. Since plants are more likely to adopt water reuse the higher the water price, policymakers could increase the value of water charges so as to provide firms with incentives to implement water reuse practices. Alternatively, as reuse decisions seem also to be influenced by the capital price, part of the water charge revenues collected within the Paraíba do Sul river basin could be used to provide subsidized credits to firms intending to adopt water reuse practices.

The water demand equations demonstrate the expected negative elasticity with respect to the freshwater price, meaning that an increase in the freshwater price results in a decrease of the water demand. In addition to that, the estimated water price elasticity is larger for plants that reuse water than for those which do not. This result indicates that water charges will have a more effective impact in terms of water demand reduction among plants that reuse water. There are two possible explanations for the discrepancy in the 
water price elasticity estimates. First, plants that reuse water usually have larger water cost shares than plants that do not. As a result, the former can be expected to be more sensitive to changes in water prices. Second, the difference in price elasticities could be explained by the substitution possibilities between water reuse and freshwater withdrawals, which are only available to plants which adopt water reuse practices. The positive coefficient for the water reuse price, indicating that freshwater and recycled water are substitute inputs, provides some empirical support to the argument that substitution patterns may explain the differences in the price elasticities. Finally, our results also indicate that when analyzing the water demand structure separately for plants that reuse water and those which do not, one should take into account nonrandom sampling problems. If the water demand equations were estimated separately with no correction for sample selection, the coefficient estimates would like to be biased.

\section{References}

Amemya, T. (1981). "Qualitative Response Models: A Survey", Journal of Economic Literature, 19(4), pp.1483-1536.

Anderson, J. (2003). "The Environmental Benefits of Water Recycling and Reuse", Water Science and Technology: Water Supply, 3(4), pp.1-10.

Dupont, D. and S. Renzetti (2001). "The Role of Water in Manufacturing", Environmental and Resource Economics, 18(4), pp.411-432.

Esquivel, G. and F. Larraín (1998). Explaining Currency Crises. Development Discussion Paper No.666, Harvard Institute for International Development.

Féres, J. and A. Reynaud (2005). "Assessing the Impact of Environmental Regulation on Industrial Water Use: Evidence from Brazil”, Land Economics, 81(3), pp. 396-411.

Féres, J., A. Reynaud, A. Thomas and R. Seroa da Motta (2005). Competitiveness and Effectiveness Concerns in Water Charge Implementation: A Case Study of the Paraiba do Sul River Basin, Brazil. Mimeo.

Grebenstein, C. and B. Field (1979). "Substituting for Water Inputs in U. S. Manufacturing”, Water Resources Research, 15(2), pp.228-232.

Greene, W. H. (1996). Econometric Analysis, $3^{\text {rd }}$ edition. New Jersey: Prentice Hall

Maddala, G. S. (1983). Limited Dependent and Qualitative Variables in Econometrics. New York: Cambridge University Press.

Renzetti, S. (1992). "Estimating the Structure of Industrial Water Demands: The Case of Canadian Manufacturing", Land Economics 68(4), pp.396-404. 
Reynaud, A. (2002). "An Econometric Estimation of Industrial Water Demand in France", Environmental and Resource Economics, 25(2), pp.213-232.

Scharf, D., D. W. Burke, M. Villeneuve and L. Leigh (2002). Industrial Water Use, 1996. Ottawa: Minister of Public Works and Government Services Canada.

Tate, D. M. and D. N. Scharf (1995). Water Use in Canadian Industry, 1991, Social Science Series No. 31. Ottawa: Environment Canada, Water and Habitat Conservation Branch.

United Nations Environment Program, UNEP (2005). Water and Wastewater Reuse. UNEP: International Environmental Technology Centre. 